\title{
Characterization of Functional Opioid Delta Receptors in a Luteinizing Hormone-Releasing Hormone-Producing Neuronal Cell Line*
}

\author{
ROBERTO MAGGI, FEDERICA PIMPINELLI, LUCIANO MARTINI, AND FLAVIO PIVA
}

Department of Endocrinology, University of Milan, 20133 Milan, Italy

\begin{abstract}
Endogenous opioids participate in the regulation of gonadotropin secretion through an influence on the release of the hypothalamic LHRH. However, it is not clear whether opioids exert a direct effect on LHRH-producing neurons or interfere with other systems able to influence LHRH release.

A neuronal LHRH-producing cell line (GT1) developed recently provides a good model to study the mechanisms controlling LHRH release. In the present study, the presence of opioid receptors on a subclone of GT1 cells (GT1-1) has been investigated. A specific and saturable binding of the ${ }^{3} \mathrm{H}$-labeled nonselective opioid ligand diprenorphine $\left(\left[{ }^{3} \mathrm{H}\right] \mathrm{DIP}\right)$ was detected by a receptor binding assay on both intact GT1-1 cells and crude membrane preparations obtained from these cells. Analysis of saturation curves revealed that $\left[{ }^{3} \mathrm{H}\right] \mathrm{DIP}$ apparently binds to a single class of sites with a $\mathrm{K}_{\mathrm{d}}$ of $0.2 \mathrm{nM}$ and a binding capacity of $125 \mathrm{fmol} / \mathrm{mg}$ protein, corresponding to approximately 20,000 sites/cell. Selective displacement of the binding of $\left[{ }^{3} \mathrm{H}\right] \mathrm{DIP}$ to GT1-1 cells by [D-Ala ${ }^{2}, N-\mathrm{Me}-\mathrm{Phe}^{4}, \mathrm{Gly}^{5}$-ol]enkephalin,
\end{abstract}

$\left[D-P e n^{2}, D-P e n^{5}\right.$ ]enkephalin (DPDPE), and U50488H, which are selective ligands, respectively, for $\mu$-, $\delta$-, and $\kappa$-receptors, was also evaluated. Only the specific $\delta$-ligand DPDPE produced a significant inhibition of the binding of $\left[{ }^{3} \mathrm{H}\right] \mathrm{DIP}$. [D-Ala ${ }^{2}, N-\mathrm{Me}-\mathrm{Phe}^{4}, \mathrm{Gly}^{5}$ ol]Enkephalin and U50488H were totally ineffective. The inhibitory effect of the agonist DPDPE on the binding of $\left[{ }^{3} \mathrm{H}\right] \mathrm{DIP}$ was decreased by the presence of sodium ions, a typical characteristic of the binding of agonists to opioid receptors. Finally, it has been observed that treatment with prostaglandins $\mathrm{E}_{1}$ and $\mathrm{E}_{2}$ produces a dramatic increase in cAMP accumulation in GT1-1 cells, and DPDPE is highly effective in suppressing this effect. On the basis of these results, it is possible to postulate the presence of functional $\delta$-opioid receptors on GT1-1 cells. By extrapolation, one might suggest that endogenous opioids may affect LHRH neurons by two mechanisms: a direct one, acting via $\delta$-receptors, and an indirect one, through the activation of neurons impinging on the LHRH system, which uses $\mu$-receptors. (Endocrinology 136: 289-295, 1995)
$\mathrm{T}$ HE SECRETION of anterior pituitary gonadotropins is under the control of the hypothalamic hormone LHRH $(1,2)$. Several studies have shown that the neurons that synthesize LHRH are innervated by multiple neuronal pathways, which use different neurotransmitter systems. It is via these pathways that extrahypothalamic structures may modify LHRH release and, consequently, modulate gonadotropin secretion $(3,4)$. The study of the neurons that synthesize LHRH is made difficult by the peculiar anatomy of the LHRH system, which is composed of only a few hundred neurons scattered in the hypothalamic area.

A promising tool for the investigation of these interactions became available recently, when an immortalized line of LHRH-producing neurons (the GT1 cell line) was developed; this was obtained by targeted tumorigenesis in transgenic mice (5). The three subclones of the GT1 cells so far obtained (GT1-1, GT1-3, and GT1-7) (5) show the phenotypic characteristics of neuronal cells and synthesize and secrete abundant amounts of LHRH (5-7). If one assumes that these cell lines reflect the biological characteristics of physiological I.HRH-synthesizing neurons, they may be used to extend our

Received August 10, 1994.

Address all correspondence and requests for reprints to: Dr. Roberto Maggi, Department of Endocrinology, Via G. Balzaretti 9, 20133 Milan, Italy.

* This work was supported by the CNR through Projects ACRO 93.02197PF39 and 94.01162PF39, BTBS 93.01103PF70, Aging 93.00438PF40 and 94.00470PF40, and FATMA 93.00700PF41 and by MURST. knowledge on the physiology of LHRH-secreting cells. Recently, it has been shown that the GT1 cells possess the receptors for several families of neurotransmitters known to modify LHRH secretion, such as those for norepinephrine $(8$, $9)$, dopamine $(9,10), \gamma$-aminobutyric acid (11), excitatory amino acids $(12,13)$, endothelin (14), etc.

It is known that among the transmitters involved in the control of LHRH release, the endogenous opioid peptides (Met- and Leu-enkephalin, dynorphin, and $\beta$-endorphin) play a particularly relevant role $(1,15-18)$. It has been repeatedly shown that opioid agonists (e.g. morphine) inhibit gonadotropin release, and that opioid antagonists (e.g. naloxone) stimulate LH output (19-21). However, little is known about the site where opioids act to modulate gonadotropin secretion. There is no clear-cut evidence on a possible direct effect of natural and synthetic opioids on LHRHproducing neurons, because of the methodological difficulty in studying LHRH neurons in vivo. The majority of the reports available support the view that the effects of opioids on the LHRH-secreting system might be indirect, via the interaction with intermediate neuronal systems that influence LHRH secretion through the release of their specific neurotransmitters (18).

As no data are available on the presence of opioid receptors on the neurons synthesizing LHRH, it was felt to be of interest to verify whether opioid receptors might be present on GT1 cells. To this purpose, the possible binding of the nonselective opioid ligand diprenorphine (DIP) on GT1-1 cells was first analyzed, using both membrane preparations 
and intact cells. As it is known that opioids exert their effects through the interaction with at least three subclasses of specific binding sites (named, respectively, $\mu, \delta$, and $\kappa)(22,23)$, it was subsequently attempted to clarify whether one or more subclasses of opioid receptors might be present on this LHRH-producing cell line.

\section{Materials and Methods}

\section{Cell cultures}

GT1-1 cells, generously provided by Dr. R. I. Weiner (San Francisco, CA) through Dr. B. Marchetti (Catania, Italy), were routinely grown in monolayer at $37 \mathrm{C}$ in a humidified $\mathrm{CO}_{2}$ incubator in Dulbecco's Minimum Essential Medium containing $1 \mathrm{~mm}$ sodium pyruvate, 100 $\mu \mathrm{g} / \mathrm{ml}$ streptomycin, $100 \mathrm{U} / \mathrm{ml}$ penicillin, and $10 \mathrm{mg} /$ liter phenol red (Biochrom KG, Berlin, Germany) and supplemented with $10 \%$ fetal calf serum (Gibco, Grand Island, NY). The medium was replaced at 2-day intervals. Subconfluent cells were routinely harvested by trypsinization and seeded in $57-\mathrm{cm}^{2}$ dishes $\left(1 \times 10^{6}\right.$ cells) for propagation. GT1-1 cells within six passages were used throughout the experiments. To obtain crude cell membrane preparations, GT1-1 cells at subconfluence were harvested in Dulbecco's PBS solution (DPBS) without calcium and magnesium salts and containing $0.4 \%$ EDTA; the cellular pellet, obtained by centrifugation, was subsequently washed in DPBS. The cells were then homogenized in $0.32 \mathrm{M}$ sucrose solution in $5 \mathrm{~mm}$ Tris- $\mathrm{HCl}, \mathrm{pH} 7.4$, by seven strokes in a glass-Teflon potter kept in ice. The cell homogenate was then centrifuged $(750 \times g$ at $4 \mathrm{C}$ for $10 \mathrm{~min})$; the resulting supernatants were incubated for $30 \mathrm{~min}$ at $37 \mathrm{C}$ and then further centrifuged $30 \mathrm{~min}$ at $40,000 \times g$ at $4 \mathrm{C}$. The supernatant was decanted, and the pellet (crude membrane preparation) was used in the receptor binding assay.

For receptor binding assay on intact cells and CAMP experiments, GT1-1 cells were plated in 12- or 24-wells plates $\left(0.5 \times 10^{6}\right.$ cells $\left./ \mathrm{cm}^{2}\right)$ and used after 3 days of culture. All samples were assayed for protein content using a microassay (24) with human serum albumin as a standard.

\section{Receptor binding assay}

The receptor binding assay was performed using [15,15-N- $\left.{ }^{3} \mathrm{H}\right] \mathrm{DIP}$ ( $\mathrm{SA}, 31 \mathrm{Ci} / \mathrm{mmol}$; Amersham, Milan, Italy) as opioid ligand. The binding assay on crude membrane preparations was performed as previously described (25). The competition curves were performed by incubation of $0.1 \mathrm{nM}\left[{ }^{3} \mathrm{H}\right] \mathrm{DIP}$ in the absence and presence of the selective opioid agonists [D-Ala ${ }^{2}, N-M e-P_{h}^{4}, G^{5}{ }^{5}$-ol]enkephalin (DAGO), [D-Pen ${ }^{2}, \mathrm{D}-$ Pen ${ }^{5}$ lenkephalin (DPDPE; Sigma Chemical Co., St. Louis, MO), and trans-( \pm )-3,4-dichloro- $N$-methyl- $N$-[2-(1-pyrrolidinyl)cycloexyl]benzenacetamide methane sulfonate (U-50488H), kindly provided by Upjohn Co. (Kalamazoo, MI).

The binding of $\left[{ }^{3} \mathrm{H}\right] \mathrm{DIP}$ to intact cells was evaluated using the method described by Cone et al. (26) with minor modifications. Briefly, GT1-1 cells growing in multiwell plates were preincubated for $10 \mathrm{~min}$ in $0.5 \mathrm{ml}$ binding buffer [50 mM Tris- $\mathrm{HCl}(\mathrm{pH} 7.4), 1 \%$ BSA, and $0.5 \mathrm{mg} / \mathrm{ml}$ bacitracin] containing $100 \mathrm{~mm} \mathrm{NaCl}$ at room temperature. During the last $2 \mathrm{~min}$ of the preincubation, the plates were kept at $4 \mathrm{C}$ to adapt the cells to the assay incubation temperature. The preincubation buffer was then replaced with $0.5 \mathrm{ml}$ binding buffer containing the tracer $\left[{ }^{3} \mathrm{H}\right] \mathrm{DIP}$. Nonspecific binding was assessed by the addition of $1 \mu \mathrm{M}$ unlabeled naltrexone. For competition experiments, unlabeled opioids were added simultaneously to the tracer. After incubation at $4 \mathrm{C}$ for $2 \mathrm{~h}$, the cell monolayers were washed three times with DPBS, solubilized in $0.5 \mathrm{ml}$ $0.2 \mathrm{M} \mathrm{NaOH}$, neutralized with $1 \mathrm{M} \mathrm{HCl}$, mixed with $7 \mathrm{ml}$ scintillation cocktail (Instagel, Packard, Milan, Italy), and counted in a Packard 1600 CA liquid scintillation spectrometer with $60 \%$ efficiency.

\section{cAMP assay}

The intracellular cAMP accumulation was measured over a $15-\mathrm{min}$ incubation period with $1 \mu \mathrm{M}$ prostaglandin $\mathrm{E}_{1}\left(\mathrm{PGE}_{1}\right)$ or $10 \mu \mathrm{M}$ prostaglandin $\mathrm{E}_{2}\left(\mathrm{PGE}_{2} ;\right.$ Sigma) as activators of adenylyl cyclase after a 10-min preincubation with $0.5 \mathrm{~mm}$ 3-isobutyl-1-methylxanthine (Sigma). A commercially available binding protein assay kit (Amersham) was used to evaluate cAMP levels in ethanol-extracted cells according to the manufacturer's instructions.

\section{Statistical analysis}

Receptor binding experiments were optimized with the program Design (27), and the results were further analyzed by the program Ligand (28), adapted to a Macintosh computer by Dr. G. E. Rovati (Institute of Pharmacological Sciences, Milan, Italy).

The dose-response curves were analyzed by means of a Macintosh version of the program Allfit (29), kindly provided by Dr. V. Guardabasso (Cyanamid, Catania, Italy).

\section{Results}

\section{Studies on GT1-1 cell membrane preparations}

Receptor binding experiments have shown the presence of specific binding of the opioid ligand $\left[{ }^{3} \mathrm{H}\right] \mathrm{DIP}$ to crude membrane preparations obtained from GT1-1 cell homogenates. Such binding attains equilibrium in $30 \mathrm{~min}$ at $25 \mathrm{C}$ and is totally inhibited by an excess $(1 \mu \mathrm{M})$ of unlabeled nonselective opioid ligands such as bremazocine and naltrexone, which leave a low (5\%) residual nonspecific binding (data not shown).

As illustrated in Fig. 1, the binding of $\left[{ }^{3} \mathrm{H}\right] \mathrm{DIP}$ to membrane preparations of GT1-1 cells is saturable and characterized by a high affinity $\left(\mathrm{K}_{\mathrm{d}}, 0.2 \mathrm{nM}\right)$, which is of the same order of maynitude as that in membranes obtained from the whole mouse brain $\left(\mathrm{K}_{\mathrm{d}}, 0.1 \mathrm{nM}\right)$. The maximal binding capacity $\left(B_{\max }\right)$ of $\left[{ }^{3} \mathrm{H}\right] \mathrm{DIP}$, normalized per $\mathrm{mg}$ protein incubated, seems to be lower in GT1-1 cell membranes than in mouse brain (125 fmol/mg protein for GT1-1 cell membranes vs. $156 \mathrm{fmol} / \mathrm{mg}$ protein for mouse brain). However, the two results are not directly comparable due to the dif-

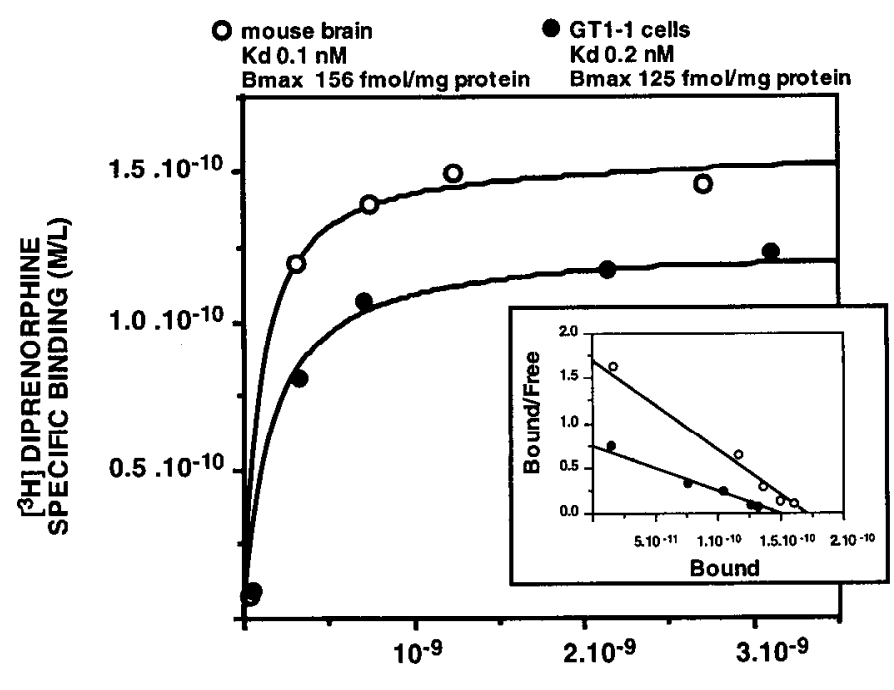

[3H] DIPRENORPHINE (ML)

FIG. 1. Specific binding of increasing concentrations of $\left[{ }^{3} \mathrm{H}\right] \mathrm{DIP}$ to mouse brain and GT1-1 cell membrane preparations. Nonspecific binding was determined in the presence of $1 \mu \mathrm{M}$ naltrexone. The saturation isotherms were analyzed by the Ligand program (28), and the binding parameters $B_{\max }$ and $K_{d}$ were determined. The data are also represented as a Scatchard plot (inset) and are representative of two independent experiments performed in duplicate. 
ferent sources of the starting materials (i.e. a homogeneous cell line $v$ s. an extract of heterogeneous brain tissues containing different types of cells).

As $\left[{ }^{3} \mathrm{H}\right] \mathrm{DIP}$ is known to label with approximately equal affinity brain $\mu, \delta$, and $\kappa$ sites, the possible presence in GT1-1 cells of the different subclasses of opioid receptors and their relative proportions were further investigated by selective inhibition of the specific binding of $\left[{ }^{3} \mathrm{H}\right] \mathrm{DIP}$. The selective opioid ligands DAGO, DPDPE, and U50488H were used to inhibit the binding of $\left[{ }^{3} \mathrm{H}\right] \mathrm{DIP}$, respectively, to $\mu-, \delta$-, and $\kappa$-receptors. Two concentrations of each selective ligand were used to obtain a submaximal and a maximal mask of their relative binding sites. The results show that at 1-nM concentrations, the three specific ligands had no significant inhibitory effect on $\left[{ }^{3} \mathrm{H}\right] \mathrm{DIP}$ binding (Fig. 2). At higher concentrations $(100 \mathrm{nM})$, only the specific $\delta$-ligand DPDPE inhibited (up to $60 \%$ ) the specific binding of [ $\left.{ }^{3} \mathrm{H}\right] \mathrm{DIP}$ to GT1-1 membranes (Fig. 2). The pure $\mu$ - and $\kappa$-ligands DAGO and U50488H were practically ineffective in inhibiting $\left[{ }^{3} \mathrm{H}\right] \mathrm{DIP}$ binding even at the higher concentration (Fig. 2). These results may be indicative of the presence of only $\delta$-opioidbinding sites on the membranes of GT1-1 cells.

The characteristics of the inhibitory effect of DPDPE on $\left[{ }^{3} \mathrm{H}\right] \mathrm{DIP}$ binding were further investigated by heterologous displacement curves. The analysis of these curves shows that DPDPE inhibits the specific binding of $1 \mathrm{~nm}\left[{ }^{3} \mathrm{H}\right] \mathrm{DIP}$ on GT1-1 cell membranes in a dose-related fashion, with a $\mathrm{K}_{\mathrm{i}}$ of $5.5 \mathrm{~nm}$ and maximal inhibition $(>90 \%)$ at the $1-\mu \mathrm{M}$ concentration (Fig. 3).

One of the characteristics of opioid receptors resides in the decrease in the binding of opioid agonists (but not of opioid antagonists) induced by the presence in the medium of monovalent ions, in particular sodium ions (30,31). The potency of the agonist DPDPE in displacing $\left[{ }^{3} \mathrm{H}\right] \mathrm{DIP}$ binding on GT1-1 membrane preparations was then assessed in the presence of sodium ions. As expected, the binding of the

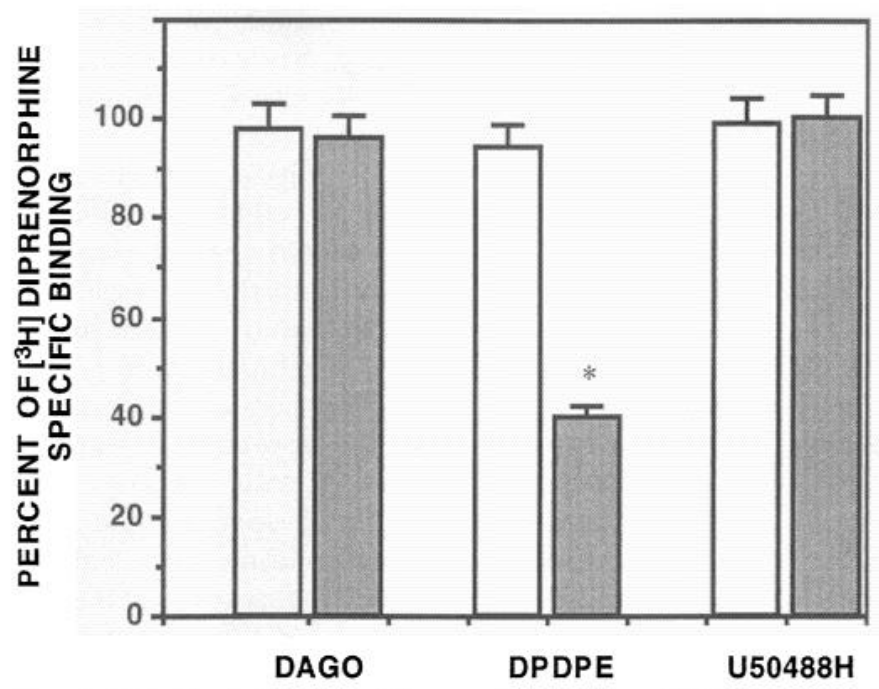

FIG. 2. Selective inhibition of the specific binding of $\left[{ }^{3} \mathrm{H}\right] D I P(0.5 \mathrm{nM})$ by $\mu$ (DAGO)-, $\delta$ (DPDPE)-, and $\kappa$ (U50488H)-selective ligands. $\left[{ }^{3} \mathrm{H}\right] \mathrm{DIP}$ was incubated with $1 \mathrm{nM}(\square)$ or $100 \mathrm{nM}(\boldsymbol{\square})$ of the specific opioid agonists. Values are the mean \pm SEM of triplicate determinations obtained from two independent experiments. ${ }^{*}, P<0.05 \mathrm{vs}$. $\left[{ }^{3} \mathrm{H}\right] \mathrm{DIP}$-specific binding in the absence of opioid agonists.

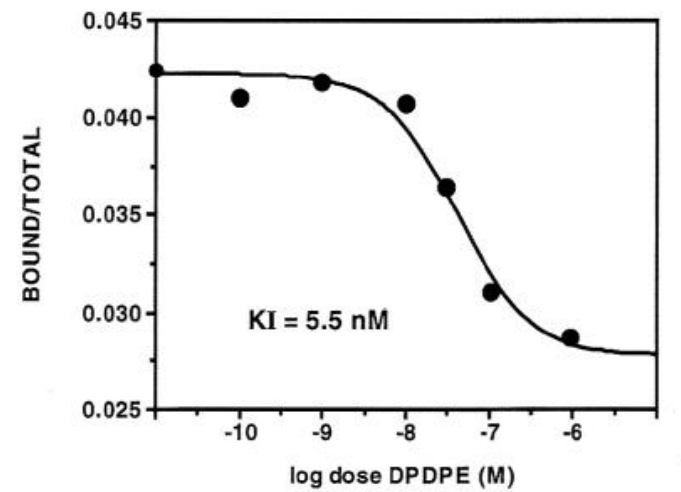

FIG. 3. Inhibition of the binding of [ $\left.{ }^{3} \mathrm{H}\right] \mathrm{DIP}$ to GT1-1 cell membrane preparations by the selective $\delta$-agonist DPDPE. $\left[{ }^{3} \mathrm{H}\right] \mathrm{DIP}(0.5 \mathrm{nM})$ was incubated with various concentrations of DPDPE. The values represent one of two independent experiments performed in triplicate. The $\mathrm{K}_{\mathrm{i}}$ of DPDPE was calculated using the Ligand program (28).

antagonist $\left[{ }^{3} \mathrm{H}\right] \mathrm{DIP}$ was not changed in the presence of 100 $\mathrm{mM} \mathrm{NaCl}$ (data not shown), whereas a significant increase in the $\mathrm{IC}_{50}$ of DPDPE was observed (Table 1).

\section{Studies on intact GT1-1 cells}

To rule out the possibility that the results obtained might be due to artefacts linked to the mechanical disruption of membrane integrity and cytoskeletal ultrastructures during homogenization, the binding of $\left[{ }^{3} \mathrm{H}\right] \mathrm{DIP}$ was also assessed in intact GT1-1 cells. The analysis of the saturation curve of $\left[{ }^{3} \mathrm{H}\right] \mathrm{DIP}$ to intact GT1-1 cells shows that in these conditions, specific binding of the labeled ligand occurs; this is characterized by the same $K_{d}$ value $(0.23 \mathrm{nM})$ previously observed in membrane preparations. The density of receptors labeled by $\left[{ }^{3} \mathrm{H}\right] \mathrm{DIP}$ in intact cells appears to be $38 \mathrm{fmol} / \mathrm{mg}$ protein, corresponding to approximately 20,000 sites/cell, with a nonspecific binding of $5 \%$ (Fig. 4). The binding of $\left[{ }^{3} \mathrm{H}\right] \mathrm{DIP}$ to intact GT1-1 cells is presumably due to an interaction with receptors located on the cellular membrane (26) and not to internalization of the tracer. In fact, an acid wash (PBS, pH 3 , for 6 min at $4 \mathrm{C}$ ) performed on intact GT1-1 cells previously incubated under standard conditions with $\left[{ }^{3} \mathrm{H}\right] \mathrm{DIP}$ (see $\mathrm{Ma}$ terials and Methods) removes more than $85 \%$ of the $\left[{ }^{3} \mathrm{H}\right] \mathrm{DIP}$ bound to these cells. Selective inhibition of the specific binding of $\left.{ }^{3} \mathrm{H}\right] \mathrm{DIP}$ to intact GT1-1 cells also shows that only those ligands that bind preferentially the $\delta$-opioid receptors (i.e. DPDPE) are able to inhibit the binding of the tracer (Table 2). DPDPE inhibits the binding of $\left[{ }^{3} \mathrm{H}\right] \mathrm{DIP}$ to intact cells with a $\mathrm{K}_{\mathrm{i}}$ of $14.5 \mathrm{nM}$, and its inhibitory potency is significantly

TABLE 1. Effect of sodium ions on the potency of DPDPE to displace the binding of $\left[{ }^{3} \mathrm{H}\right] \mathrm{DIP}$ to GT1-1 cell membrane preparations

\begin{tabular}{cc}
\hline Treatment & $\mathrm{IC}_{50}$ (nM) \\
\hline Control & $15.1 \pm 1.6$ \\
$\mathrm{NaCl}(100 \mathrm{mM})$ & $63.7 \pm 7.7^{\alpha}$ \\
\hline
\end{tabular}

Values \pm SD were obtained by Allfit (29) analysis of competition curves, performed in triplicate.

${ }^{a} P<0.05$ vs. control. 


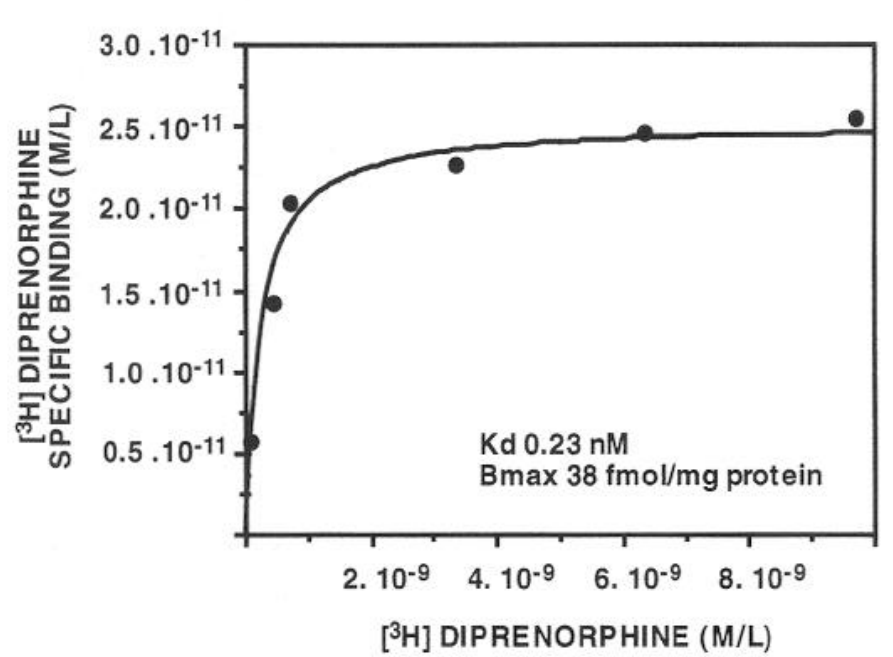

FIG. 4. Specific binding of increasing concentrations of $\left[{ }^{3} \mathrm{H}\right] \mathrm{DIP}$ to intact GT1-1 cells. Nonspecific binding was determined in the presence of $1 \mu \mathrm{M}$ naltrexone. The saturation isotherms were analyzed by the Ligand program (28), and the binding parameters $B_{\max }$ and $K_{d}$ were determined. Data are representative of two independent experiments performed in duplicate.

TABLE 2. Effects of several opioid agonists on the binding of $\left[{ }^{3} \mathrm{H}\right] \mathrm{DIP}$ to intact GT1-1 cells

\begin{tabular}{lc}
\hline $\begin{array}{c}\text { Agonists } \\
(100 \mathrm{nM})\end{array}$ & $\begin{array}{c}\text { \% of }\left[{ }^{3} \mathrm{H}\right] \mathrm{DIP} \\
\text { specific binding }\end{array}$ \\
\hline DAGO & $102.0 \pm 3.9$ \\
DPDPE & $81.9 \pm 0.6^{a}$ \\
U50488H & $103.7 \pm 2.4$ \\
\hline
\end{tabular}

Data are expressed as the mean \pm SEM of two experiments performed in triplicates.

${ }^{a} P<0.05$ vs. percent specific binding of $\left[{ }^{3} \mathrm{H}\right] \mathrm{DIP}$ in the absence of the agonists $(100 \%)$.

reduced, as in the studies on membrane preparations, by the presence of $100 \mathrm{~mm} \mathrm{NaCl}$ in the incubation medium (Table 3).

\section{Opioid inhibition of cAMP accumulation in GT1-1 cells}

The effect of DPDPE on the activation of adenyl cyclase induced by different stimuli was studied in GT1-1 cells by measuring the intracellular accumulation of cAMP. As illustrated in Fig. 5, the basal levels of cAMP found in control cells were not modified by a $10-\mu \mathrm{M}$ concentration of the $\delta$-opioid agonist DPDPE. The addition to GT1-1 cells of $1 \mu \mathrm{M}$ PGE $_{1}$ dramatically enhanced cAMP accumulation (8.6-fold over prestimulated levels at the end of the $15 \mathrm{~min}$ of treatment). $\mathrm{PGE}_{2}$ also showed a strong stimulatory effect on cAMP accumulation. However, the stimulatory effects on the intracellular cAMP concentration induced by both $\mathrm{PGE}_{1}$ and

TABLE 3. Effect of sodium ions on the potency of DPDPE to displace the binding of $\left[{ }^{3} \mathrm{H}\right] \mathrm{DIP}$ to intact GT1-1 cells

\begin{tabular}{lc}
\hline \multicolumn{1}{c}{ Treatment } & $\mathrm{IC}_{50}(\mathrm{nM})$ \\
\hline Control & $92.1 \pm 12.0$ \\
$\mathrm{NaCl}(100 \mathrm{mM})$ & $1138.2 \pm 106.9^{a}$ \\
\hline
\end{tabular}

Values \pm SD were obtained by Allfit (29) analysis of competition curves, performed in triplicate.

${ }^{a} P<0.05$ vs. control.

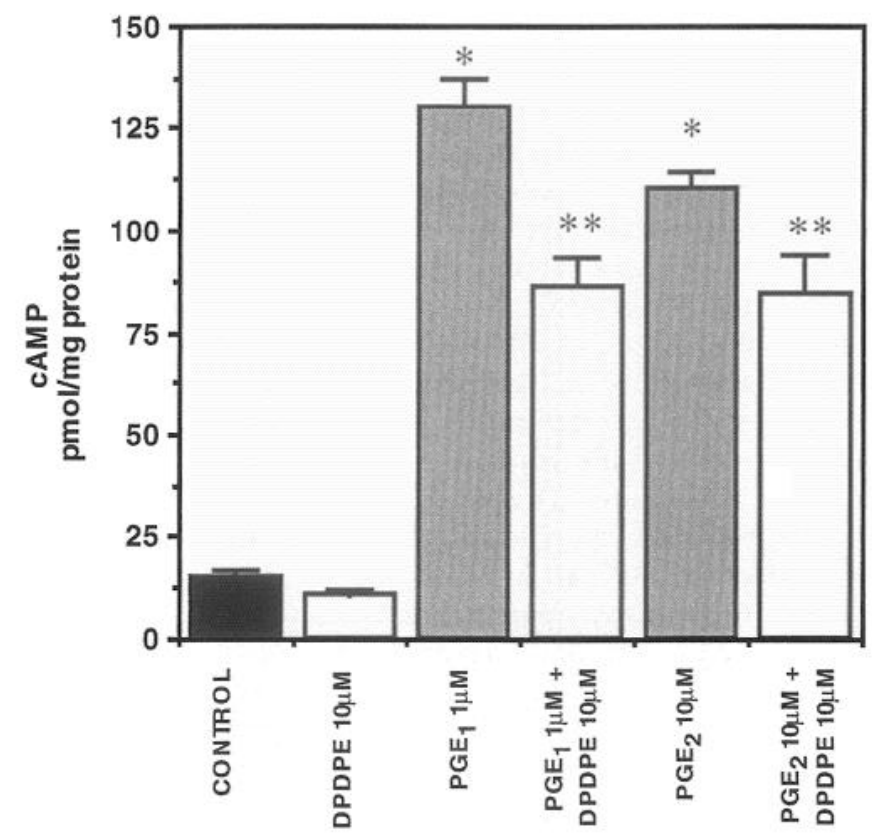

FIG. 5. Inhibition of $\mathrm{PGE}_{1}$ - and $\mathrm{PGE}_{2}$-stimulated cAMP accumulation in GT1-1 cells by the opioid delta agonist DPDPE. Cells were incubated for $30 \mathrm{~min}$ with 3 -isobutyl-1-methylxanthine $(0.5 \mathrm{mM})$ in serum-free medium; $\mathrm{PGE}_{1}(1 \mu \mathrm{M})$ or $\mathrm{PGE}_{2}(10 \mu \mathrm{M})$, alone or with DPDPE $(10 \mu \mathrm{M})$, was then added for the last $15 \mathrm{~min}$ of culture. Values are the mean \pm SEM of quadruplicate determinations obtained from two independent experiments. ${ }^{*}, P<0.05 \mathrm{vs}$. control; ${ }^{* *}, P<0.05 \mathrm{vs}$. PG-treated cells.

$\mathrm{PGE}_{2}$ were significantly reduced by coincubation with $10 \mu \mathrm{M}$ DPDPE by $44 \%$ and $33 \%$ respectively (Fig. 5).

\section{Discussion}

The results described in the present study provide the first evidence showing that LHRH-producing GT1-1 cells express opioid receptors. The nonselective opioid antagonist $\left[{ }^{3} \mathrm{H}\right] \mathrm{DIP}$ binds with high affinity $(0.2 \mathrm{nM})$ to both crude cell membrane preparations as well as intact GT1-1 cells. The binding affinity of $\left[{ }^{3} \mathrm{H}\right] \mathrm{DIP}$ to GT1-1 cells is similar to that reported for this opiate when tested on membrane preparations obtained from either rat brain or neuroblastoma cells (26, 32-35).

The binding of $\left[{ }^{3} \mathrm{H}\right] \mathrm{DIP}$ to GT1-1 cells is characterized by low nonspecific binding and is similar to that observed in crude membrane preparations of whole mouse brain. $\left[{ }^{3} \mathrm{H}\right] \mathrm{DIP}$ binds with approximately equal affinity to $\mu-, \delta$-, and $\kappa$-opioid receptors $(22,32,36)$; consequently, it is not possible to discriminate, using only this approach, the type(s) of opioid receptor(s) present on GT1-1 cells. Selective displacement experiments performed with specific opioid ligands revealed the presence only of binding sites of the $\delta$ type. Indeed, in the membrane preparation studies, the selective ligand for $\delta$-opioid receptors, DPDPE, strongly inhibits ( $>90 \%$ at $1 \mu \mathrm{M}$ ) the binding of $\left[{ }^{3} \mathrm{H}\right] \mathrm{DIP}$, which, on the contrary, is not affected by selective ligands for the $\mu$ - and $\kappa$-opioid-binding sites. The $\mathrm{K}_{\mathrm{i}}$ for DPDPE $(5.5 \mathrm{nM})$ calculated on the present results is very similar to the $\mathrm{K}_{\mathrm{i}}$ or $\mathrm{K}_{\mathrm{d}}$ found for labeled DPDPE on $\delta$ sites present in membrane preparations obtained from rodent brain or neuroblastoma cells $(35,37-$ 
39). The presence of only binding sites of the $\delta$ type was also confirmed in intact GT1-1 cells (see below).

A further characterization of these receptors was performed by analyzing their sensitivity to sodium ions. It is well known that the binding of $\mu$-and $\delta$-agonists is decreased in the presence of sodium ions, a phenomenon that does not occur when opioid antagonists are used. From the data obtained, it is evident that the presence of sodium in the incubation buffer induces a significant decrease in the potency of DPDPE to inhibit the binding of [ $\left.{ }^{3} \mathrm{H}\right] \mathrm{DIP}$ to either membrane preparations or intact GT1-1 cells. This results in increases in the $\mathrm{K}_{\mathrm{i}}$ and $\mathrm{IC}_{50}$.

As previously mentioned, the presence of $\delta$-opioidbinding sites was confirmed when the binding experiments were repeated on intact GT1-1 cells. However, the selective inhibitory effect of the $\delta$-ligand DPDPE on the binding of $\left[{ }^{3} \mathrm{H}\right]$ DIP was slightly lower in intact GT1-1 cells than that found in crude membrane preparations. It is well known that the binding of $\mu$ - and $\delta$-agonists is decreased not only in the presence of sodium ions, but also by GTP (34). As the binding experiments on intact GT1-1 cells were performed in a sodium-free buffer, it is possible that the decreased displacing activity of DPDPE might be due to the presence of GTP or to a combined effect of GTP and residual intracellular sodium (31). Recently, the cloning of $\delta$-opioid receptors has been reported (40-42); an assessment of the expression of messenger RNA for the $\delta$-opioid receptors in GT1-1 cells is presently under way and will provide a definitive evidence of their presence in these LHRH-secreting cells.

It is well known that opioids may exert inhibitory effects on the stimulated accumulation of CAMP in several cells and tissues $(23,43,44)$. To investigate whether the $\delta$-opioid receptors identified on GT1-1 cells are functional, the ability of the $\delta$-agonist DPDPE to inhibit the stimulation of cAMP accumulation induced in GT1-1 cells by treatment with two known activators of adenylyl cyclase, $\mathrm{PGE}_{1}$ and $\mathrm{PGE}_{2}$, was analyzed (45). The results obtained clearly showed that both PGs are strong stimulators of CAMP accumulation in GT1-1 cells, and that the activation of $\delta$-opioid receptors by DPDPE leads to a significant decrease in the stimulated cAMP levels. The data presented here are consistent with the numerous observations of an inhibitory role exerted by the opioids on intracellular cAMP accumulation (43-47) and indicate that the $\delta$-receptors reported on GT1-1 cells are functional. In addition, the ability to inhibit cAMP accumulation as well as the sensitivity to sodium ions suggest a functional coupling of the $\delta$-receptor subtype present in GT1-1 cells to intracellular effector molecules such as the GTP-binding proteins $(22,23)$. In experiments presently in progress, it has been shown that the $\delta$-opioid agonist DPDPE inhibits LHRH secretion in GT1-1 cells elicited by forskolin (Maggi, R., F. Pimpinelli, L. Martini, and F. Piva, in preparation).

The presence of opioid-binding sites on the subclone of GT1 cells used in the present experiments is relevant, especially in light of the possible role of these receptors in the control of LHRH release and expression. If one assumes that GT1 cells represent a good model for the study of LHRHsecreting neurons, the obvious conclusion from these data is that endogenous opioid peptides may influence LHRH se- cretion by acting directly on LHRH-secreting neurons. A second conclusion would be that this effect of the opioids is mediated by the $\delta$-subclass of receptors. Obviously, it must be pointed out that the present data do not exclude the possibility that opioids act on the release of LHRH via other mechanisms (see below). As mentioned in the introduction, a large body of evidence implicates opioid peptides in the central mechanisms controlling gonadotropins and LHRH secretion $(1,15,17-20)$. The prevailing theory proposes that opioid neurons have synaptic contacts with intermediatc neurons, which, in turn, influence LHRH neurons via the local release of their respective neurotransmitters $(18,48)$. However, a few reports have demonstrated that, at least in rats (49-51), monkeys (52), and cows (53), opioid neurons (particularly POMC or $\beta$-endorphin reactive) may entertain direct synaptic contacts with hypothalamic LHRH-immunoreactive neurons, suggesting the possibility of a direct effect of physiological opioids. In contradistinction with the present data, which shows the presence of $\delta$-receptors on LHRH-producing neurons, a number of data obtained in vivo, especially in the rat, support the view that opioids affect LHRH release mainly through the interaction with opioid receptors of the $\mu$ type (54-57). However, a few studies have also implicated $\delta(58-60)$ - and $\kappa(58,59)$-receptors in such a mechanism. For instance, Leadem et al. $(58,59)$ have shown that $\Delta$-agonists, including DPDPE, induce a biphasic effect on LH secretion in ovariectomized rats after intraventricular injection. In this connection, one may also point out that $\beta$-endorphin binds with similar affinities to $\mu$ and $\delta$ sites (22, 36 ). It must be recalled that the relative proportions of opioid receptor subtypes are different in the brains of various animal species (61). For instance, in the forebrain of the mouse (the species from which GT1 cells are derived), there is 25\% more $\delta$-receptor and $40 \%$ less $\mu$-receptor than in the forebrain of the rat, suggesting a predominantly $\delta$-receptor composition in the mouse brain (61). Moreover, in the mouse, both the hypothalamus and preoptic area contain the same amounts of $\mu$ - and $\delta$-opioid receptors (62), whereas in the rat, the concentration of $\Delta$ sites is extremely low in the hypothalamus $(39,61,63)$, a structure in which a relatively high concentration of $\mu$-receptors is present in this species $(61,63)$.

In conclusion, from the data here presented, when analyzed in conjunction with the evidence just described, we hypothesize that the effects of physiological opioid peptides on LHRH secretion consist of two distinct components: the first, acting directly on the $\delta$-receptors present on the LHRHsynthesizing neurons, and the second acting via intermediate neurons, where opioids probably interact mainly with the $\mu$-receptor subfamily.

\section{References}

1. McCann SM 1991 Neuroregulatory peptides. In: Motta M (ed) Brain Endocrinology. Comprehensive Endocrinology. Raven Press, New York, vol 2:1-30

2. Kalra SP, Kalra PS 1991 Steroid-peptide interactions in the endocrine brain: reproduction. In: Motta M (ed) Brain Endocrinology. Comprehensive Endocrinology. Raven Press, New York, vol 2:177216

3. Weiner RI, Findell PR, Kordon C 1987 Role of classic and peptide neuromediators in the neuroendocrine regulation of $\mathrm{LH}$ and pro- 
lactin. In: Knobil E, Neill JD (eds) The Physiology of Reproduction. Raven Press, New York, pp 1235-1281

4. Silverman AJ 1988 The gonadotropin-releasing hormone (GnRH) neuronal systems: immunocytochemistry. In: Knobil E, Neill JD (eds) The Physiology of Reproduction. Raven Press, New York, pp 1283-1304

5. Mellon PL, Windle JJ, Goldsmith PC, Padula CA, Roberts JL, Weiner RI 1990 Immortalization of hypothalamic GnRH neurons by genetically targeted tumorigenesis. Neuron 5:1-10

6. Liposits Z, Merchenthaler I, Wetsel WC, Reid JAJ, Mellon PL, Weiner RI, Negro-Vilar A 1991 Morphological characterization of immortalized hypothalamic neurons synthesizing luteinizing hormone-releasing hormone. Endocrinology 129:1575-1583

7. Weiner RI, Wetsel W, Goldsmith P, Martinez de la Escalera G, Windle J, Padula C, Choi A, Negro-Vilar A, Mellon P 1992 Gonadotropin-releasing hormone neuronal cell lines. In: Ganong WF, Martini L (eds) Frontiers in Neuroendocrinology. Raven Press, New York, vol 13:95-119

8. Martinez de la Escalera G, Choi ALH, Weiner RI 1992 B1-Adrenergic regulation of the GT1 gonadotropin-releasing hormone (GnRH) neuronal cell lines: stimulation of GnRH release via receptors positively coupled to adenylate cyclase. Endocrinology 131: 1397-1402

9. Martinez de la Escalera G, Gallo F, Choi ALH, Weiner RI 1992 Dopaminergic regulation of the GT1 gonadotropin-releasing hormone (GnRH) neuronal cell lines: stimulation of $\mathrm{GnRH}$ release via $D_{1}$-receptors positively coupled to adenylate cyclase. Endocrinology 131:2965-2971

10. Findell PR, Wong KH, Jackman JK, Daniels DV $1993 \beta_{1}$-Adrenergic and dopamine (D1)-receptors coupled to adenyl cyclase activation in GT1 gonadotropin-releasing hormone neurosecretory cells. Endocrinology 132:682-688

11. Hales TG, Kim H, Longoni B, Olsen RW, Tobin AJ 1992 Immortalized hypothalamic GT1-7 neurons express functional $\gamma$-aminobutyric acid type A receptors. Mol Pharmacol 42:197-202

12. Urbanski HF, Fahy MM, Daschel M, Meshul C 1994 N-Methyl-Daspartate receptor gene expression in the hamster hypothalamus and in immortalized luteinizing hormone-releasing hormone neurones. J Reprod Fertil 100:5-9

13. Mahachoklertwattana P, Sanchez J, Kaplan SL, Grumbach MM $1994 \mathrm{~N}$-Methyl-D-aspartate (NMDA) receptors mediate the release of gonadotropin-releasing hormone ( $\mathrm{GnRH})$ by NMDA in a hypothalamic GnRH neuronal cell line (GT1-1). Endocrinology 134:10231030

14. Moretto M, Lopez FJ, Negro-Vilar A 1993 Endothelin-3 stimulates luteinizing hormone-releasing hormone (LHRH) secretion from LHRH neurons by a prostaglandin-dependent mechanism. Endocrinology 132:789-794

15. Meites J, Bruni JF, Van Vugt DA, Smith AF 1979 Relation of endogenous opioid peptides and morphine to neuroendocrine function. Life Sci 24:1325-1336

16. Motta M, Martini L 1982 Effect of opioid peptides on gonadotrophin secretion. Acta Endocrinol (Copenh) 99:321-326

17. Martini L, Dondi D, Limonta P, Maggi R, Piva F 1989 Modulation by sex steroids of brain opioid receptors: implications for the control of gonadotropins and prolactin secretion. J Steroid Biochem 33:673681

18. Kalra SP 1993 Mandatory neuropeptide-steroid signaling for the preovulatory luteinizing hormone-releasing hormone discharge. Endocr Rev 14:507-538

19. Piva F, Maggi R, Limonta P, Motta M, Martini L 1985 Effect of naloxone on luteinizing hormone, follicle-stimulating hormone and prolactin secretion in the different phases of the estrus cycle. Endocrinology 117:766-772

20. Piva F, Limonta P, Maggi R, Martini L 1986 Stimulatory and inhibitory effects of the opioids on gonadotropin secretion. Neuroendocrinology 42:504-512

21. Kalra SP 1986 Neural circuitry involved in the control of LHRH secretion: a model for preovulatory $\mathrm{LH}$ release. In: Martini L, Ganong WF (eds) Frontiers in Neuroendocrinology. Raven Press, New York, pp 31-75

22. Leslie FM 1987 Methods used for the study of opioid receptors. Pharmacol Rev 39:197-249
23. Wolleman M 1990 Recent developments in the research of opioid receptor subtype molecular characterization. J Neurochem 54:10951101

24. Bradford MM 1976 A rapid and sensitive method for the quantification of microgram quantities of protein utilizing the principle of protein-dye binding. Anal Biochem 72:248-254

25. Maggi R, Dondi D, Rovati GE, Martini L, Piva F, Limonta P 1993 Binding characteristics of hypothalamic $\mathrm{mu}$ opioid receptors throughout the estrous cycle in the rat. Neuroendocrinology 58: 366-372

26. Cone RI, Lameh J, Sadée W 1991 Rapid agonist-induced loss of ${ }^{125} \mathrm{I}-\beta$-endorphin opioid receptor sites in NG108-15, but not SKN-SH neuroblastoma cells. Life Sci 49:PL147-PL152

27. Rovati GE, Rodbard D, Munson PJ 1988 DESIGN: computerized optimization of experimental design for estimating $\mathrm{Kd}$ and $\mathrm{Bmax}$ in ligand binding experiments. I. Homologous and heterologous binding to one classes of sites. Anal Biochem 174:636-649

28. Munson PJ, Rodbard D 1980 LIGAND: a versatile computerized approach for characterization of ligand-binding systems. Anal Biochem 107:220-239

29. De Lean A, Munson PJ, Rodbard D 1978 Simultaneous analysis of families of sigmoidal curves: application to bioassay, radioligand assay, and phisiological dose-response curves. Am J Physiol 235: E97-E102

30. Pert CB, Snyder SH 1974 Opiate receptor binding of agonists and antagonists affected differentially by sodium. Mol Pharmacol 10: $868-879$

31. Puttfarcken P, Werling LL, Brown SR, Cote TE, Cox BM 1986 Sodium regulation of agonist binding at opioid receptors. I. Effects of sodium replacement on binding at $\mu$ - and $\delta$-type receptors in 7315c and NG108-15 cells and cell membranes. Mol Pharmacol 30:81-89

32. Magnan J, Paterson S, Tavani A, Kosterlitz H 1982 The binding spectrum of narcotic analgesic drugs with different agonist and antagonist properties. Naunyn Schmiedebergs Arch Pharmacol 319: 197-205

33. Louie AK, Bass ES, Zhan J, Law PY, Loh HH 1990 Attenuation of opioid receptor activity by phorbol esters in neuroblastoma $\times$ glioma NG108-15 hybrid cells. J Pharmacol Exp Ther 253:401-407

34. Werling LL, Puttfarcken PS, Cox BM 1988 Multiple agonist-affinity states of opioid receptors: regulation of binding by guanyl nucleotides in guinea pig cortical, NG108-15, and 7315c cell membranes. Mol Pharmacol 33:423-431

35. Kazmi SI, Mishra RK 1987 Comparative pharmacological properties and functional coupling of $\mu$ and $\delta$ opioid receptor sites in human neuroblastoma SI I-SY5Y cells. Mol Pharmacol 32:109-118

36. Paterson SJ, Robson LE, Kosterlitz HW 1983 Classification of opioid receptors. Br Med Bull 39:31-36

37. Corbett A, Gillan M, Kosterlitz H, McKnight A, Paterson S, Robson L 1984 Selectivities of opioid peptide analogues as agonists at the delta-receptor. Br J Pharmacol 83:271-279

38. Hochhaus G, Yu VC, Sadée W 1986 Delta opioid receptors in human neuroblastoma cell lines. Brain Res 382:327-331

39. Dondi D, Maggi R, Limonta P, Martini L, Piva F 1992 Binding characteristics of delta opioid receptors in different regions of the brain of young and old male rats as studied with the highly selective ligand [D-PEN2-D-PEN5] enkephalin. Aging Clin Exp Res 4:69-75

40. Evans CJ, Keith Jr DE, Morrison H, Magendzo K, Edwards RH 1992 Cloning of delta opioid receptor by functional expression. Science 258:1952-1955

41. Kieffer BL, Befort K, Gaveriaux-Ruff C, Hirth CG 1992 The $\delta$-opioid receptor: isolation of a cDNA by expression cloning and pharmacological characterization. Proc Natl Acad Sci USA 89:1204812052

42. Yasuda K, Raynor K, Kong H, Breder CD, Takeda J, Reisine T, Bell GI 1993 Cloning and functional comparison of kappa and delta opioid receptors from mouse brain. Proc Natl Acad Sci USA 90: $6736-6740$

43. Law PY, Hom DS, Loh HH 1983 Opiate receptor down-regulation and desensitization in neuroblastoma $\times$ glioma NG108-15 hybrid cells are two separate cellular adaptation processes. Mol Pharmacol 24:413-424

44. Yu CV, Eiger S, Duan D-S, Lameh J, Sadée W 1990 Regulation of 
cyclic AMP by the $\mu$-opioid receptor in human neuroblastoma $\mathrm{SH}$ SY5Y cells. J Neurochem 55:1390-1396

45. Yu CV, Hochhaus G, Chang F-S, Richards ML, Bourne HR, Sadée W 1988 Differentiation of human neuroblastoma cells: marked potentiation of prostaglandin E-stimulated accumulation of cyclic AMP by retinoic acid. J Neurochem 51:1892-1899

46. Yu CV, Sadée $\mathbf{W} 1988$ Efficacy and tolerance of narcotic analgesics at the mu opioid receptor in differentiated human neuroblastoma cells. J Pharmacol Exp Ther 245:350-355

47. Wang JF, Shun XJ, Yang HF, Ren MF, Han JS 1993 Suppression by $\left[\mathrm{D}-\mathrm{Pen}^{2}, \mathrm{D}-\mathrm{Pen}^{5}\right.$ ] enkephalin on cyclic AMP dependent protein $\mathrm{ki}-$ nase-induced, but not protein kinase $\mathrm{C}$-induced increment of intracellular free calcium in NG108-15 cells. Life Sci 52:1519-1525

48. Kalra SP, Simpkins JW 1981 Evidence for noradrenergic mediation of opioid effects on LH secretion. Endocrinology 109:776-782

49. Leranth C, MacLusky NJ, Shanabrough M, Naftolin F 1988 Immunohistochemical evidence for synaptic connections between proopiomelanocortin-immunoreactive axons and LH-RH neurons in the preoptic area of the rat. Brain Res 449:167-176

50. Chen W-P, Witkin JW, Silverman AJ 1989 -Endorphin and gonadotropin releasing hormone synaptic input to gonadotropin releasing hormone neurosecretory cells in the male rat. J Comp Neurol 286:85-95

51. Hoffman GE, Fitzsimmons MD, Watson Jr RE 1989 Relationship of endogenous opioid peptide axons to $\mathrm{GnRH}$ neurons in the rat. In: Dyer RG, Biknell RJ (eds) Brain Opioid Systems in Reproduction. Oxford University Press, Oxford, pp 125-134

52. Thind KK, Goldsmith PC 1988 Infundibular gonadotropin releasing hormone neurons are inhibited by direct opioid and autoregulatory synapses in juvenile monkeys. Neuroendocrinology 47:203216

53. Leshin LS, Rund LA, Kraeling RR, Crim JW, Kiser TE 1992 Distribution of $\beta$-endorphin immunoreactivity in the arcuate nucleus and median eminence of postpartum anestrus and luteal phase cows. Neuroendocrinology 56:436-444
54. Pfeiffer DG, Pfeiffer A, Shimohigashi Y, Merriam GR, Loriaux DL 1983 Predominant involvement of mu- rather than delta- or kappaopiate receptors in LH secretion. Peptides 4:647-649

55. Pancrai AE, Petraglia F, Sacerdote P, Genazzani AR 1985 Mainly $\mu$-opiate receptors are involved in luteinizing hormone and prolactin secretion. Endocrinology 117:1096-1099

56. Pfeiffer DG, Pfeiffer A, Almeida OFX, Herz A 1987 Opiate suppression of LH secretion involves central receptors different from those mediating opiate effects on prolactin secretion. J Endocrinol $114: 469-476$

57. Landymore KM, Wilkinson M 1988 Influence of neonatal opioid blockade or injections of gonadotropin-releasing hormone on the timing of puberty in female rats: correlation of opioid effects with occupation of hypothalamic $\mu$-opioid receptors. J Endocrinol 119: $447-452$

58. Leadem CA, Kalra SP 1985 Effects of endogenous opioid peptides and opiates on luteinizing hormone and prolactin secretion in ovariectomized rats. Neuroendocrinology 41:342-352

59. Leadem CA, Yagenova SV 1987 Effects of specific activation of mu-, delta- and kappa-opioid receptors on the secretion of luteinizing hormone and prolactin in ovariectomized rat. Neuroendocrinology 45:109-117

60. Gerozissis K, Dragatsis I, Zioudrou C 1993 The $\delta$-opioid signal transduction on the gonadotropin-releasing hormone release is eicosanoid dependent. Brain Res 626:219-224

61. Mansour A, Khachaturian H, Lewis ME, Akil H, Watson SJ 1988 Anatomy of CNS opioid receptors. TINS 11:308-314

62. Moskowitz AS, Goodman RR 1984 Light microscopic autoradiographic localization of $\mu$ and $\delta$ opioid binding sites in the mouse central nervous system. J Neurosci 4:1331-1342

63. Sharif NA, Hughes J 1989 Discrete mapping of brain mu and delta opioid receptors using selective peptides: quantitative autoradiogrphy, species differences and comparison with kappa receptors. Peptides 10:499-522 